\title{
Em Defesa de um Campo: a Sociologia da Sexualidade
}

LAURA MOUTINHO

\author{
BOZON, Michel. Sociologie de la Sexualité. \\ Paris: Nathan, 2002, 127 p.
}

Sociologie de la Sexualité, escrito por Michel Bozon, compõe uma interessante coleção francesa intitulada Domaine Sciences Sociales publicada pela Editora Nathan, sob a coordenação editorial de François de Singly.

A afirmação peremptória que abre a reflexão proposta no livro surpreende: "La sociologie de la sexualité n'existe pas"2. O texto subseqüente, ao delinear os objetivos do livro, esclarece um pouco o sentido desta frase de impacto. Além de se configurar como uma introdução e um mapa para aqueles que desejam iniciar os estudos sobre sexualidade, o livro de Michel Bozon tem como proposta a defesa e a construção de um campo - o da sociologia - para a abordagem da temática vis-à-vis as disciplinas legitimadas na análise (e construção) da sexualidade, como por exemplo, a psicanálise, a sexologia e a psicologia clínica, que apóiam suas estratégias de legitimação tanto na reflexão sobre os problemas e questões individuais relativos à sexualidade quanto nas intervenções possibilitadas pela prática clínica.

Nesse sentido, o objetivo central do livro é apontar as contribuições que a sociologia pode trazer para o estudo, a compreensão e (por que não dizer) a construção da sexualidade humana. Para tanto, o autor explicita, ainda na introdução, o ponto de partida que permite analisar a sexualidade sob a perspectiva sociológica: a espécie humana não é conduzida pelo cio. A vida sexual humana depende da socialização que enreda a atividade sexual à complexa dinâmica sócio-histórica.

Ao retirar a sexualidade da esfera da natureza, Michel Bozon aponta não somente para a multiplicidade de construções e vivências histórico-culturais possíveis, como evidencia que a sexualidade se configura como uma conve- 
niente e vantajosa porta de entrada para a compreensão das relações sociais mais amplas. A sexualidade se apresenta, na sociedade ocidental, como uma esfera autônoma, relacionada, porém, a outros domínios sociais, que, em verdade, lhe concedem sentido, significado e organização. Nas palavras do autor: "socialement construite par le contexte culturel où elle est inscrite, elle tire son importance politique de ce qu'elle contribue en retour à structurer les rapports sociaux dont elle dépend en les 'incorporant' et en les représentant" 3

O livro compreende três partes: na primeira, mais histórica, Michel Bozon discorre sobre o surgimento da moderna sexualidade, sua construção como um domínio autônomo e central para a construção do sujeito. Na segunda parte, encontramos a sexualidade circunscrita ao domínio das relações sociais. Por fim, o autor nos apresenta alguns dos cenários contemporâneos dos espinhosos caminhos do desejo. Trata-se de um livro de difícil controle para o leitor, dadas suas características de desbravar o campo da sociologia da sexualidade, ao mesmo tempo em que objetiva atingir, paralelamente, um público mais amplo. Neste sentido, o autor percorre o tema agrupando variados estudos que foram produzidos sob essa rubrica, mobilizando comparativamente distintos contextos socioculturais e os inter-relacionando com diversas outras áreas de conhecimento que abordam o tema da sexualidade: provocando interlocuções e, igualmente, evidenciando pontos de tensão. Esses aspectos se configuram, justamente, como um dos pontos positivos do trabalho, pois apresenta (e organiza), de modo fluente e claro, questões, discussões e tendências profundamente complexas.

Na primeira parte do livro, intitulada "Transformations de la sexualité et émergence de la subjectivité moderne", Michel Bozon segue o percurso da sexualidade marcada pela procriação, inscrita (e inscrevendo) uma ordem mais fixa das diferenças entre os sexos para a sexualidade construída como um domínio autônomo, marcada pela noção de indivíduo e produtora da subjetividade moderna.

O lugar da procriação como um dos fundamentos da vida social e a lógica androcêntrica que organiza as representações sociais sobre a diferença sexual aparecem tanto a partir da lógica classificatória binária e hierárquica, base do pensamento simbólico (na qual o feminino aparece como inferior ao masculino), quanto de um ponto de vista histórico e etnográfico.

Eis, neste enquadramento inicial, as primeiras indicações do tipo de contribuição que a sociologia pode fornecer para o estudo da sexualidade. $\mathrm{O}$ idioma do sexo, da sexualidade e do gênero reflete, constitui e explicita as 
relações de poder. Nesse caminho, diversos elementos aparecem como indicativos das relações de força diferenciadas entre os gêneros, como, por exemplo, a forma pela qual distintos grupos sociais designam as relações sexuais, mobilizando sentidos e significados sociais diversos. No caso do Brasil, as metáforas alimentares relativas ao ato sexual explicitam tanto a dominação masculina quanto fornecem instrumentos para a construção das identidades sexuais. Do mesmo modo, as fronteiras entre o lícito e o ilícito e a própria iniciação sexual, cujos limites e possibilidades expõem as desigualdades entre os gêneros e informam sobre as construções (e vivências) diferenciadas relativas à sexualidade, à masculinidade e a feminilidade.

Na segunda parte, "Sexualité et rapports sociaux", Michel Bozon apresenta a vida sexual seguindo suas principais questões e vivências no interior dos ciclos e etapas da vida social. O foco, neste ponto, é deslocado para os contextos socioculturais específicos que informam e circunscrevem os roteiros e as condutas sexuais: as novas codificações e normatizações da sexualidade são analisadas a partir da conduta e da educação sexual dos jovens e adolescentes, o ciclo da vida de um casal, novas formas de conjugalidade hetero e homossexuais, a vivência da sexualidade na velhice e as novas interações (e tensões) das relações geracionais e de gênero, de classe, migratórias e étnicas.

Por ser um livro escrito para francês ler, o leitor brasileiro tem condições de aproveitar interessantes informações sobre diversos países (com destaque, aqui, para os dados e tendências apresentados sobre alguns países da Europa, em particular a França), que inclusive nos instigam a cotejar com as pesquisas sobre sexualidade realizadas no Brasil e a identificar alguns pontos cegos das representações sociais e acadêmicas brasileiras (e mesmo internacionais) sobre a temática.

Nesse sentido, por exemplo, além dos aspectos acima mencionados, cabe destacar a análise empreendida sobre erotismo e pornografia - uma lacuna no Brasil, na área de sexualidade. Ao analisar "les constructions du désir e du plasir" - aqui, entramos na terceira parte do livro - Michel Bozon segue o percurso histórico das representações culturais sobre a pornografia e o erotismo, até desembocar nos novos roteiros que organizam a vida sexual, que intervêm na produção do desejo sexual e orientam a leitura das sensações corporais e da própria construção de si. Dentre as novas normatizações da sexualidade, a medicina e psicologia clínica adquirem um lugar proeminente, com seus discursos e práticas sobre o funcionamento sexual saudável. 
Na parte final do livro, merece destaque o esforço do autor em circunscrever social e sociologicamente o desejo sexual: área tradicionalmente infensa ao discurso sociológico, uma vez que o desejo é freqüentemente associado à formação da psique humana individual. Na perspectiva apresentada, a vida sexual depende de produções sociais, construídas sob a forma de roteiros que codificam e estruturam as experiências sexuais ao mesmo tempo que as produzem. Mais do que se dedicar a um debate sobre o tema, o autor se empenha em fornecer subsídios teóricos e metodológicos que possibilitam abordar a temática em sua inter-relação com outros aspectos conformadores da sexualidade humana, que variam de acordo com os contextos sociais e históricos.

Ao término da leitura do livro, a frase que abre a reflexão proposta continua a ecoar, mas um novo sentido pode ser depreendido daquela afirmação. Percorrendo as páginas desse escrito, o leitor vai sendo persuadido do lugar (e da necessidade) da sociologia para a análise da sexualidade. A própria forma como o livro está estruturado sugere ao leitor a organização deste campo de estudo. Pelo que incita, apresenta e discute, pode-se dizer que se trata de um livro que merece ser traduzido.

\section{NOTAS}

1 Doutora em antropologia pelo PPGSA/IFCS/UFRJ, professora e pesquisadora visitante do IMS/ UERJ e pesquisadora do Centro Latino-Americano em Sexualidade e Direitos Humanos, vinculado ao Programa de Gênero, Sexualidade e Saúde (IMS/UERJ).

2 “A sociologia da sexualidade não existe" (p. 6).

3 “construída socialmente pelo contexto cultural onde está inscrita, ela (a sexualidade humana) deriva sua relevância política daquilo para o que ela, por sua vez, contribui para estruturar as próprias relações sociais das quais ela depende, incorporando-as e representando-as" (p. 6). 